\title{
New species and new records of the lichen genus Buellia sensu lato (Caliciaceae) from India
}

\author{
Roshinikumar Ngangom ${ }^{1,2}$, Sanjeeva Nayaka ${ }^{1,2 *}$, Rupjyoti Gogoi ${ }^{3}$, Komal Kumar Ingle ${ }^{1}$, Prashant Kumar \\ Behera $^{1}$ \& Farishta Yasmin ${ }^{3}$ \\ ${ }^{1}$ Lichenology Laboratory, CSIR-National Botanical Research Institute, Rana Pratap Marg, Lucknow, Uttar Pradesh 226 001, India \\ ${ }^{2}$ Academy of Scientific and Innovative Research (AcSIR), CSIR-HRDC Campus, Kamla Nehru Nagar, Ghaziabad, Uttar Pradesh, India \\ ${ }^{3}$ Department of Botany, Nowgong College, Nagaon, Assam 782 001, India \\ *Email: nayaka.sanjeeva@gmail.com
}

\section{ARTICLE HISTORY}

Received: 31 July 2020

Accepted: 12 September 2020

Published: 01 October 2020

\section{KEYWORDS}

Ascomycota; biodiversity; Caliciales;

lichenised fungi; taxonomy
ABSTRACT

While revising the lichen genus Buellia sensu lato from India, species Cratiria rubrum with brick red pigmented thallus is described as new to science. The new species is characterized by a red pigmented thallus, Buellia type ascospore, $\mathrm{KOH}+$ red. Five species are reported for the first time from India viz., Amandinea efflorescens, A. incrustans, Baculifera orosa, Hafellia dissa and $H$. reagens.

\section{Introduction}

Lichen genus Buellia was established by De Notaris (1) as a segregate of Lecidea Ach. The genus is cosmopolitan in distribution characterised by crustose thallus, lecideine or cryptolecanorine apothecia, usually hyaline hymenium with or without oil inspersion, reddish brown or dark brown hypothecium, brown, septate ascospores lacking internal wall thickening at least at young stage (2). Buellia is a heterogeneous taxon and its phylogeny remains unresolved due to various reasons. So far more than 16 different genera were proposed out of Buellia based on narrowly defined characters (3). Some of the early segregates include Diplotomma Flot., Tetramelas Norman, Amandinea M. Choisy and Hafellia Kalb. H. Mayrhofer \& Scheid (3).

Marbach (4) while revising the genus Buellia sensu lato from North America proposed several genera such as Chrismofulvea, Ciposia, Cratiria, Endohyalina, Fluctua, Hypoflavia, Sculptolumina and Stigmatochroma. These genera were established purely based on morphological and chemical characters and include either one or very few species. Marbach (4) concept was followed by various workers $(4,7)$ for studying of this group. As the Marbach's study was restricted only to North American species, it did not contribute significantly to resolving taxonomic complexity and phylogeny of the genus. Therefore, some of the researchers $(3,8)$ preferred to follow wider and classical concepts of the genus. The taxonomic ambiguity and phylogeny of Buellia sensu lato can only be resolved when large number of data is gathered from different parts of the world involving both morpho-chemical as well as molecular studies. Aim of the present study is to revise Indian specimens belonging to Buellia sensu lato and segregate them under most acceptable genera. In the process one species is described as new to science and five others as new distributional record to India.

From Indian subcontinent Awasthi (9) listed a total of 23 species of Buellia. Singh and Awasthi (10) revised the genus Buellia from India and provided detailed morphotaxonomic descriptions of 39 species of which 12 species were new reports for the country. Since then the genus is updated continuously with several new distributional reports and novel species (11-22). At present, Buellia sensu lato is represented by 75 species in India under genera Amandinea (8 spp.), Baculifera (3 spp.), Buellia (49 spp., still under revision as Gassicurtia), Cratiria (5 spp.), Hafellia (4 spp.), Sculptolumina (1 sp.) and Stigmatochroma (5 spp.) of

(C) Ngangom et al (2020). This is an open-access article distributed under the terms of the Creative Commons Attribution License, which permits unrestricted use, distribution and reproduction in any medium, provided the original author and source are credited (https://creativecommons.org/licenses/by/4.0/)

To cite this article: Ngangom R, Nayaka S, Gogoi R, Ingle K K, Behera P K, Yasmin F. New species and new records of the lichen genus Buellia sensu lato (Caliciaceae) from India. Plant Science Today. 2020;7(4):584-589. https://doi.org/10.14719/pst.2020.7.4.879 
which 18 are endemic. It can be noted that although there has been addition of species under the Buellia sensu lato, but the genus is not critically revised after Singh and Awasthi (10).

\section{Materials and Methods}

Specimens examined in the present study were preserved at the herbarium of CSIR-National Botanical Research Institute, Lucknow (LWG) and personal herbarium of Dr. D.D. Awasthi (LWG-AWAS) and some fresh collections from different parts of the country. The morphological observations and spot tests were conducted under a stereo zoom microscope (Leica S8 APO) and anatomical characters were observed under a compound microscope (Leica DM500). Lichens were photographed and image analysis was done using a Leica EC3 camera and LAS EZ software. All measurements were based on handcut sections of apothecia mounted on water or $10 \%$ $\mathrm{KOH}$ solution (K). Asci were observed under Lugol's solution with or without $\mathrm{K}$. Colour spots were conducted using routine reagents such as K, C, KC and P. Lichen substances were identified using thin layer chromatography (TLC) with solvent system A and C (23).

\section{Results and Discussion}

\section{The New Species}

Cratiria rubrum R. Ngangom, Nayaka \& R. Gogoi sp. nov. (Fig. 1).

\section{Mycobank No.: MB 837351}

Type: INDIA: Assam, Nagaon district, Hojai, Komorakata Reserve Forest, $26^{\circ} 0^{\prime} 7^{\prime \prime} \mathrm{N}, 92^{\circ} 46^{\prime} 48^{\prime \prime}$ E, elev. 68 m, on bark, 16 May 2016, R. Gogoi 16-036173 (Holotype-LWG).

Diagnosis: Similar to Cratiria obscurior (Stirt.) Marbach \& Kalb, but differs in having brick red thallus and uniformly coloured exciple.

Description: Thallus corticolous, crustose, areolate, areoles convex, brick red, with whitish, thin margin, round to irregular in shape, $0.2-0.3 \mathrm{~mm}$ diam.; thallus separated from neighbouring lichens by black prothallus; medulla red colour; cortex 7-9 $\mu$ m thick; photobiont Trebouxia. Apothecia sessile, black, 0.2$0.7 \mathrm{~mm}$ diam., solitary or 2-3 in groups, sessile, not constricted at base, round to slightly oval, proper margin distinct; disc flat, epruinose. Exciple lecideine, 30-60 $\mu \mathrm{m}$ thick, much wider at base, dark brown, thick and not distinctly differentiated into inner and outer layer. Epihymenium dark brown, 6-10 $\mu \mathrm{m}$ high, dissolving in $\mathrm{K}, \mathrm{I}+$ blue. Hymenium hyaline to pale brown, 30-40 $\mu \mathrm{m}$ high, not inspersed with oil globules. Hypothecium dark brown, 20-50 $\mu \mathrm{m}$ high. Paraphyses branched, apices clavate, dark brown, 3-5 $\mu \mathrm{m}$ thick. Asci up to 8-spored. Ascospore brown, ellipsoid to oblong, 14-18 × 5-7 $\mu \mathrm{m}$, 1-septate, septa thin, Buellia-type, ascospore wall evenly thickened. Pycnidia not seen.

Chemistry: Thallus and medulla $\mathrm{K}+\mathrm{red}, \mathrm{C}-, \mathrm{KC}+\mathrm{red}$, $\mathrm{P}+$ yellow, UV-, exciple $\mathrm{K}+$ red, TLC: Norstictic acid and unknown pigment of light purple colour at $R_{f}$ class 6 in solvent A.

Ecology \& distribution: Cratiria rubrum was found only in the type locality, growing on the bark of the tree in northern secondary mixed deciduous forest at an elevation of $68 \mathrm{~m}$. It was growing together with other crustose lichens such as Graphis and Lecanora.

Etymology: The species epithet 'rubrum' means red in Latin, referring to brick red pigmentation of the thallus.

Remarks: The novel species Cratiria rubrum is characterized by brick red pigmented thallus, convexly bulged areoles with pale margin, sessile, black apothecia, smaller, Buellia-type ascospores and by the presence of norstictic acid. In general morphology, chemistry and ascospore type $C$. rubrum is similar to Cratiria obscurior (Stirt.) Marbach \& Kalb but latter species differs by lacking red pigmented thallus and differentiated exciple layers. The red pigment is an unknown compound, certainly different from decomposing norstictic acid and such character is not observed in any other material studied so far. Among Buellia sensu lato all corticolous species of Gassicurtia have red pigments in thallus and smaller ascospores $(9-14 \times 4-5.5 \mu \mathrm{m})$ (4). Gassicurtia coccinoides Marbach with red pigmented thallus and Buellia-type of ascospores is similar to C. rubrum. However, G. coccinoides differs from new species in having $\mathrm{C}+$ yellow-green excipulum, UV+ orange thallus, chiodectonic acid in chemistry and lacking norstictic acid. The species $C$. rubrum is the only species among Cratiria with red pigmentation. It can be noted here that Papong et al. (24) described Diorygma roseopruinatum Papon, Lücking \& Parnmen from New Caledonia based on the presence of patchy, pink pigmented pruina on ascomata. Here the author initially mistook pink colouration for decomposing norstictic acid but latter confirmed as pigment and considered as strong character for describing a new species.

\section{New Records for India}

1. Amandinea efflorescens (Müll. Arg.) Marbach, Bibliotheca Lichenologica 74:61 (2000). - Buellia efflorescens Müll. Arg., Hedwigia 32 (3): 129 (1893). (Fig. 2A).

\section{Holotype: Singapore. VI. 1860; Maingay 158 (KEW).}

Description: Thallus corticolous, crustose, sorediate, grey to light olivaceous, verrucose, areolate; photobiont Trebouxia. Apothecia black, round, 0.3 to $0.5 \mathrm{~mm}$ diam., sessile to slightly immersed, margin distinct; disc mostly flat to slight convex, epruinose. Exciple dark brown outwards, paler inwards, up to $30 \mu \mathrm{m}$ thick. Epihymenium dark brown, K-. Hymenium hyaline, 50-60 $\mu \mathrm{m}$ high, not inspersed with oil globules. Hypothecium dark brown. Asci clavate, 8-spored. Ascospore brown, 1-septate, septa thin 12.32-16.42 × 5.02-6.55 $\mu \mathrm{m}$. Pycnidia not seen.

Chemistry: Thallus $\mathrm{K}+$ yellow, C-, KC-, P-; UV+ orange, TLC: 4,5-dichlorolichexanthone and lobaric acids (minor).

Distribution: This species is pantropical in distribution and earlier reported from North Atlantic, 

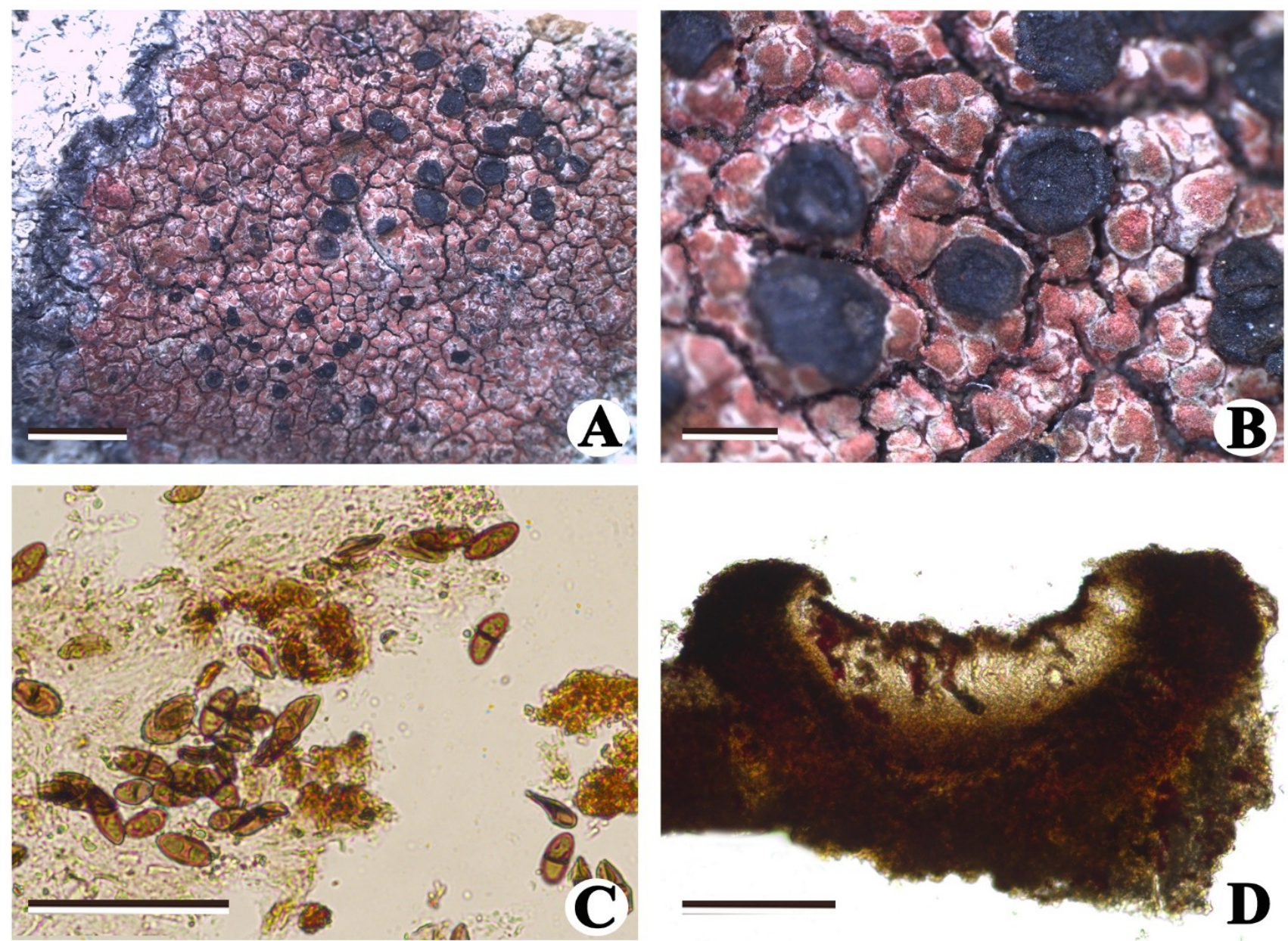

Fig. 1. Cratiria rubrum, A-B. Thallus with ascomata. C. Sections showing ascospores. D. Sections through apothecia. Scale bars: A $=2 \mathrm{~mm}$; $=0.5 \mathrm{~mm} ; \mathrm{C}=50 \mu \mathrm{m} ; \mathrm{D}=100 \mu \mathrm{m}$.

Thailand, Singapore, Puerto Rico, Guyana, Brazil, Australia, Madagascar and Seychelles (4, 25, 26).

Specimen examined: INDIA: West Bengal, Murshidabad district, Jagtai, Namitita, Samshergani block, $24^{\circ} 37^{\prime} 58.2^{\prime \prime} \mathrm{N}, 88^{\circ} 07^{\prime} 32.6^{\prime \prime} \mathrm{E}$, alt. $18 \mathrm{~m}$, on the bark of Cocos nucifera, 2015, S. Nayaka 031929 (LWG).

Remarks: Amandinea efflorescens is similar to A. diorista (Nyl.) Marbach in having UV+ thallus and 4,5dichlorolichexanthone but the latter species is esorediate (4).

2. Amandinea incrustans (J. Steiner) Marbach, Bibliotheca Lichenologica 74:75 (2000). - Buellia incrustans J. Steiner in Zahlbr., Bot. Jahrb. 60: 550 (1926). (Fig. 2B).

Holotype: Namibia: Africa austro-occidentalis, Haifischinsel in sinu Lüderitzbucht. Leg. W. Fincke; A. Zahlbruckner, Lichenes rariores exsiccati 260 (WU).

Description: Thallus saxicolous, crustose, grey to ochraceous, thick, areolate; photobiont Trebouxia. Apothecia 0.1-0.3 mm diam., sessile; disc flat, epruinose; margin distinct. Exciple blackish brown, up to $60 \mu \mathrm{m}$ thick. Epihymenium brown, K-. Hymenium hyaline, not inspersed with oil globules, up to $100 \mu \mathrm{m}$ high. Hypothecium dark brown. Asci 8- spored. Ascospores brown, 1-septate, septa thin, 13$17 \times 9-10 \mu \mathrm{m}$. Pycnidia not seen.

Chemistry: Thallus K-, C-, KC-, P-, UV-; TLC: no lichen substance detected.

Distribution: This species was earlier reported from Namid desert in South Africa (4).

Specimen examined: INDIA: Himachal Pradesh, Shimla, Kundali, Shimla Tibet road, elev. 2743 m, on rock, May 1949, H. C. Rghuber, 427 (LWG-AWAS).

Remarks: A. incrustans is similar to Amandinea extenuata (Müll. Arg.) Marbach in having ochraceous thallus and lacking lichen substances, but the latter species differs by having a less developed, thinner, warty to verrucose-areolate thallus and smaller apothecia (27).

3. Baculifera orosa Marbach, Bibliotheca Lichenologica 74: 138 (2000). (Fig. 2C).

Holotype: Mexico: Chiapas: About $10 \mathrm{~km} \mathrm{NW}$ of Comitan de Domingues, in a shady, dry oak-pine forest, 2150 msm: I. 1979; K. Kalb \& G. Plöbst 28763 (KALB).

Description: Thallus corticolous, crustose, grey, slightly to moderately verrucose, areolate, black to dark grey prothallus; photobiont Trebouxia. Apothecia $0.5-1.0 \mathrm{~mm}$ diam., sessile; disc flat to 

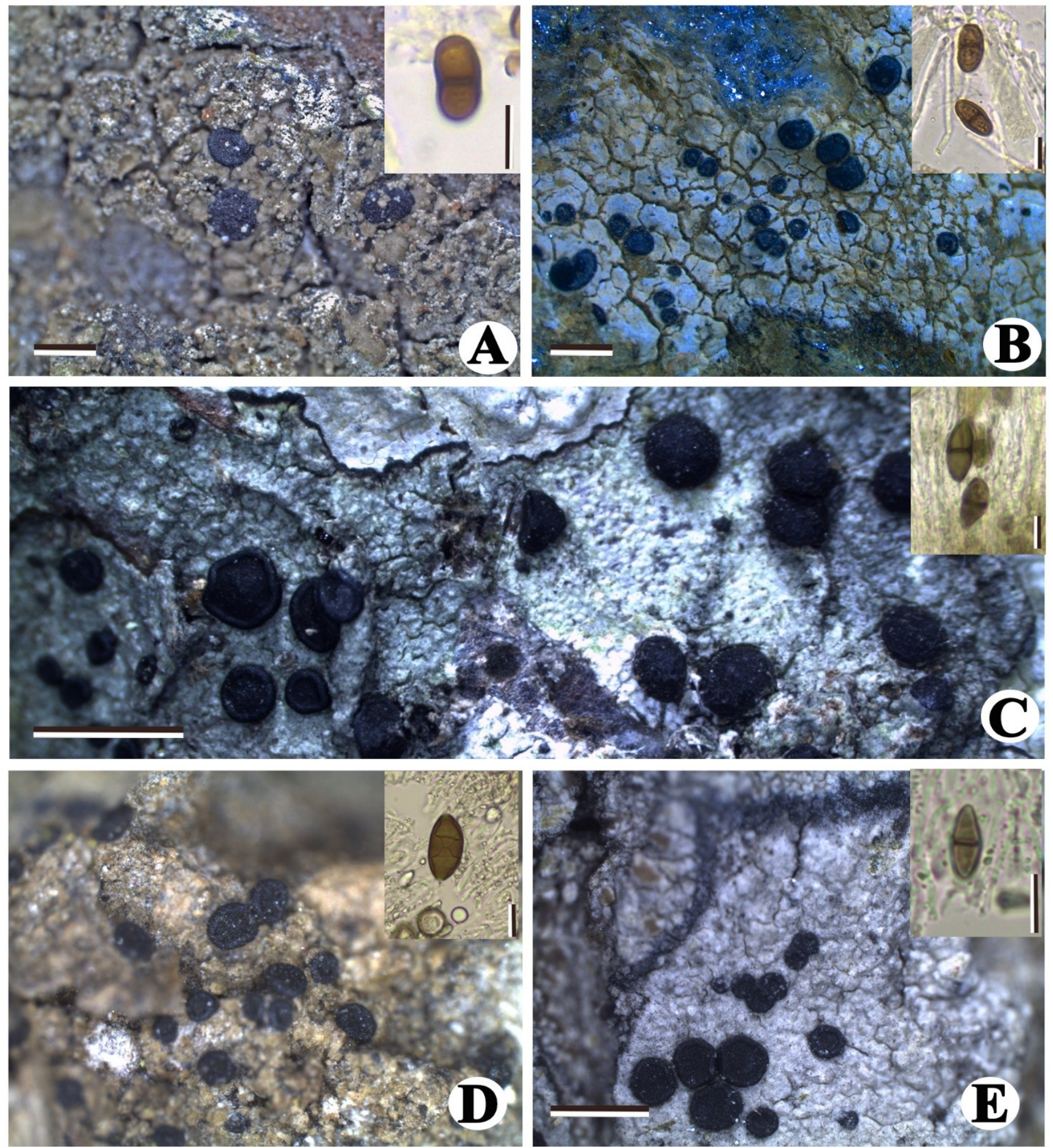

Fig. 2. A. Amandinea efflorescens. B. Amandinea incrustans. C. Baculifera orosa. D. Hafellia dissa. E. Hafellia reagens. Scale bars: A-B $=0.5 \mathrm{~mm} ; \mathrm{C}=1.5 \mathrm{~mm}$; $=0.5 \mathrm{~mm}$; $=1 \mathrm{~mm}$. Spores: $\mathrm{A}-\mathrm{E}=10 \mu \mathrm{m}$.

concave, sometimes convex, epruinose; margin distinct. Exciple dark brown to carbonaceous, 50-70 $\mu \mathrm{m}$ thick. Epihymenium dark brown to olive brown. Hymenium, hyaline, 90-100 $\mu \mathrm{m}$ high, not inspersed with oil globules. Hypothecium dark brown. Asci 8spored. Ascospores olive brown to dark brown, 1-septate, septa thin, $19-21 \times 8-10 \mu \mathrm{m}$. Pycnidia not seen.

Chemistry: Thallus $\mathrm{K}+\mathrm{red}, \mathrm{C}-, \mathrm{KC}-, \mathrm{P}+$ yellow, UV-, TLC: Norstictic acid present.
Distribution: This species was earlier reported from Central America and Mexico (4).

Specimen examined: INDIA: Nagaland, Tuensang district, Khudei village, near village Panchayat Court, $26^{\circ} 15^{\prime} 9.80^{\prime \prime} \mathrm{N} 94^{\circ} 45^{\prime} 47.60^{\prime \prime} \mathrm{E}$, elev. $2002 \mathrm{~m}$, on bark, 03 October 2018, R. Ngangom 18-035372 (LWG).

Remarks: Baculifera orosa has similar thallus chemistry with $B$. longispora Marbach but the latter species differs by the absence of prothallus and the presence of larger ascospores of more than $27 \mu \mathrm{m}$ (4). 
4. Hafellia dissa (Stirt.) H. Mayrhofer \& Sheard, Bryologist 95(1): 87 (1992), —Lecidea dissa Stirt., Trans. Glasgow Soc. Fld Nat. 4: 94 (1875). —Buellia dissa (Stirton) Zahlbr., Cat. Lich. Univ. 7:375 (1931). Rinodina dissa (Stirton) H. Mayrhofer, Beih. Nova Hedwigia 79: 532 (1984). - Catillaria dissa (Stirt.) Zahlbr., Cat. Lich. Univers. 4: 16 (1926) [1927]. (Fig. 2D).

\section{Isotype: Australia: Tasmania. 1875; Paton (BM).}

Description: Thallus corticolous, crustose, thin, smooth to verrucose, areolate, pale grey; photobiont Trebouxia. Apothecia $0.2-1 \mathrm{~mm}$., adnate to sessile; disc black, plane, usually persistent. Exciple carbonized, dark red-brown, paler in the inner part. Epihymenium brown, 10-20 $\mu \mathrm{m}$ thick. Hymenium red-brown, 90-130 $\mu \mathrm{m}$ high, inspersed with oil globules. Asci 2-spored. Ascospores Callispora-type with regular apical and septal wall thickenings, 1-septate, ellipsoid, brown, 25-42 × 12-15 $\mu \mathrm{m}$. Pycnidia pyriform, immersed; conidia bacilliform, 3$5 \times 1 \mu \mathrm{m}$.

Chemistry: Thallus $\mathrm{K}+$ yellow, C-, KC-, P-; TLC: Atranorin.

Distribution: Earlier this species was reported from cool temperate regions of Tasmania, Southern Australia, Brazil, Philippines and South Africa $(4,28)$.

Specimen examined: INDIA: Uttarakhand, Uttarkashi district, Govind Wildlife Sanctuary, Sankri village, $31^{\circ} 04.542^{\prime} \mathrm{N} 78^{\circ} 10.709^{\prime} \mathrm{E}$, elev. 1916.5 \pm 11.7 m, on bark, 13 October 2015, K.K. Ingle 15-029527 (LWG).

Remarks: Hafellia dissa is similar to $H$. pseudotetrapla Pusswald in having similar thallus, chemistry and the presence of only two mature ascospores in ascus, but the latter species differs by having larger ascospores size (44-61 × $15 \mu \mathrm{m})(29)$.

5. Hafellia reagens Pusswald, Bibliotheca Lichenologica 74: 281 (2000). (Fig. 2E).

Holotype: Australia: Western Australia: Lake Yealering, along the fore-shore, $32^{\circ} 35^{\prime} \mathrm{S}, 117^{\circ} 37^{\prime} \mathrm{E}$, on Casuarina sp. 19. VIII. 1987; J.A. Elix \& M.V. Sargent 21700 (CANB).

Description: Thallus corticolous, crustose, white to grey-white, smooth to verrucose, continuous to fissured; photobiont Trebouxia. Apothecia 0.3-0.5 $\mathrm{mm}$ diam, black, round, sessile; disc flat to convex, epruinose; margin distinct. Exciple dark brown, 20$30 \mu \mathrm{m}$ thick. Epihymenium brown, $\mathrm{K}+$ violet. Hypothecium brown. Hymenium inspersed with oil droplets, 90-110 $\mu \mathrm{m}$ high. Asci 8-spored. Ascospores 1-septate, brown, 11-14 × 4-5 $\mu \mathrm{m}$, subapically strongly thickened walls, smooth. Pycnidia not seen.

Chemistry: Thallus K+ red, C-, KC-, P+ yellow, UV -, TLC: Norstictic acid present.

Distribution: This species was earlier known from subtropical Australia (4).

Specimen examined: INDIA: Assam, Hojai district, Lumding, 25 46'10.5" N 93 11'34.7" E, elev. $150 \mathrm{~m}$, on bark, 18 October 2018, S. Nayaka et al. 18-035044 (LWG).
Remarks: Hafellia reagens resembles $H$. bahiana (Malme) Sheard in having similar thallus and $\mathrm{K}+$ violet epihymenium but the latter lacks highly thickened subapical wall (4).

\section{Conclusion}

After the addition of one new species and five new records, the genus Buellia sensu lato is now represented by 81 species in India. However, the revisionary study is still in progress and this number may increase or decrease. The study will be useful for the preparation of world monograph on this genus with vast collection from India.

\section{Acknowledgements}

We are grateful to Director, CSIR-National Botanical Research Institute, Lucknow for providing laboratory facilities; Science and Engineering Board (SERB), New Delhi for providing financial support to carry out this study under project no. EMR/2016/006604, and to Dr. Siljo Joseph for his valuable suggestions. One of the authors RN thank University Grant Commission, New Delhi for providing financial assistance in the form of Junior Research Fellowship. Authors RG and FY are thankful to Department of Biotechnology, New Delhi for financial support (No. BT/04/NE/2009) through Institutional Biotech Hub at Nowgong College, Assam. (Manuscript number of CSIR-NBRI, MS/2020/06/11).

\section{Authors' contributions}

$\mathrm{RN}$ and SN collected some specimens and identified them. RN also drafted the manuscript while SN corrected it and also supervised the whole work. RG collected the specimen of new species and provided initial description of new species. KKI collected and provided description of Hafellia dissa. PKB collected and provided description of Hafellia reagens. FY provided intellectual input and supervised the work of RG.

\section{Conflict of interests}

Authors do not have any conflict of interests to declare.

\section{References}

1. Notaris GDe. Frammenti lichenografici di un lavoro inedito. Giornale Botanico Italiano. 1846;2(1):174-224.

2. Scheidegger $\mathrm{C}$. A revision of European saxicolous species of the genus Buellia de Not. and formerly included genera. Lichenologist. https://doi.org/10.1006/lich.1993.1001. 1993;25(4):315-64.

3. Bungartz F, Nordin A, Grube M. Buellia. In: Nash TH, Gries C Bungartz F, editors. Lichen Flora of the Greater Sonoran Desert Region, Volume 3. Tempe: Lichens Unlimited, Arizona State University; 2007. p. 113-179.

4. Marbach B. Corticole und lignicole Arten der Flechtengattung Buellia sensu lato in den Subtropen und Tropen. Bibliotheca Lichenologica, J Cramer Berlin. 2000;74: 1-384. 
5. Blaha J, Mayrhofer H, Elix JA. Five new saxicolous species of Amandinea (Ascomycota, Physciaceae) from New Zealand and southern Australia. Australasian Lichenology 2016;79:35-57.

6. Mayrhofer H, Ropin K, Elix JA. Two new corticolous species of Amandinea (Ascomycota, Physciaceae) from New Zealand. Australasian Lichenology. 2016;78:11-17.

7. Elix JA. New species of Gassicurtia and Stigmatochroma (Physciaceae, Ascomycota) from Queensland, Australia, Australasian lichenology. 2016;79:3-57.

8. Joshi Y, Wang XY, Lökös L, Koh YJ, Hur J-S. Notes on Lichen Genus Buellia De Not. (lichenized Ascomycetes) from South Korea. Mycobiology. 2010;38(1):65-69. https://doi.org/ 10.4489/ myco.2010.38.1.065.

9. Awasthi DD. Catalogue of lichens from India, Nepal, Pakistan and Ceylon. Beihefte zur. Nova Hedwigia 1965;17:137.

10. Singh SR, Awasthi DD. The lichen genus Buellia in India. Biological Memoirs. 1981;6:169-96.

11. Awasthi DD. A Key to the Microlichens of India, Nepal and Sri Lanka. Bibliotheca Lichenologica 1991;40:1-340.

12. Chandra S. Revision of the lichen genus Buellia de not. (Family Physciaceae) from India. Indian J Sci Res. 2019;09(2):13-20. https://doi.org/10.32606/ijsr.v9.i2.00003.

13. Haq MU, Reshi ZA, Upreti DK. Three new records of lichenised fungi from India. Check List. 2019;15:461-64. https://doi: 10.15560/15.3.461.

14. Logesh AR, Chinlampianga M, Shukla AC, Upreti DK. Studies on Lichens of Mizoram, Northeast India. Proc Natl Acad Sci, India Sect. B Biol Sci. 2015;87:445-57.https://doi.org/ 10.1007/s40011015-0592-z.

15. Makhija U, Chitale G, Dube A. Lichens of Maharashtra. Dehra Dun, India, Bishen Singh Mahendra Pal Singh; 2014.

16. Mohabe S, Nayaka S, Reddy AM, Anjali DB. Stigmatochroma microspora (Physciaceae), a new species from India. Journal on New Biological Reports. 2015;4(2):127-31

17. Pandit G. Review of lichens of the high level Ferricretes and Mesas of the North Western Ghats, India. Current Research in Environmental \& Applied Mycology. 2015;5(3):180-95. https://doi.org/10.5943/cream/5/3/3

18. Rai H, Khare R, Upreti DK, Ahti T. Terricolous lichens of India: Taxonomic keys and description. In: Rai H, Upreti DK (editors). Terricolous lichens in India, Volume 2. Morphotaxonomic
Studies. $\quad$ London, UK: $\quad$ Springer; 2014. https://doi.org/10.1007/978-1-4939-0360-3_2

19. Singh KP, Singh SR. Two new species of lichen genus Buellia from India. Geophytology. 1982;12:128-29.

20. Singh KP, Singh S. On the species of Buellia and Diplotomma from Manipur, India. Nelumbo. 1984;26:62-64.

21. Singh KP, Sinha GP. Indian Lichens: An Annotated Checklist. Kolkata, India: Botanical Survey of India; 2010.

22. Singh SR. Ecology and distribution of lichen genera Buellia and Diplotomma in India, Nepal and Sri Lanka. In: Mukherji KG (editor). Biology of Lichens. New Delhi: Aravali Books International; 1999. p. 222-47.

23. Orange A, James PW, White FJ. Micro-Chemical Methods for the Identification of Lichens. London: British Lichen Society 2001

24. Papong KB, Lücking R, Kraichak E, Parnmen S, Von KM, Lumbsch HT. Twenty-three new species in the lichen family Graphidaceae from New Caledonia (Ostropales, Ascomycota). Phytotaxa. 2014;189(1):204-231. https://doi.org/ 10.11646/phytotaxa.189.1.15.

25. Aptroot A. Preliminary checklist of the lichens of Madagascar with two new thelotremoid Graphidaceae and 131 new records. Willdenowia 2016;46(3):349-65. https://doi.org/10.3372/wi.46.46304

26. Buaruang K, Boonpragob K, Mongkolsuk P, Sangvichien E, Vongshewarat K, Polyiam W, Rangsiruji A, Saipunkaew W, Naksuwankul K, Kalb J. A new checklist of lichenized fung occurring in Thailand. MycoKeys 2017; 23:1. https://doi.org/ 10.3897/mycokeys.23.12666

27. Giralt M, van den Boom PP, Elix JA. Amandinea lobarica, a new corticolous species from Guatemala, with notes on some additional Amandinea taxa. The Lichenologist. 2015;47(4):257. https://doi.org/10.1017/S0024282915000158

28. Leite ABX, Menezes AAde, Souto LdeS, Aptroot A, Lücking R, Santos VMdos, Cáceres MEdaS. Epiphytic microlichens as indicators of phytosociological differentiation between Caatinga and Brejos de Altitude. Acta Botanica Brasilica. 2015;29(4):457-66. https://doi.org/10.1590/0102$33062015 a b b 0116$.

29. Sipman H. Artificial Key to Marbach's tropical Buellia s. $l$ with short diagnosis. 2011. http://www.bgbm.org/sipman/keys/ Trobellia.htm. Accessed on: 2020-05-15. 